\title{
Penyebaran Informasi dalam Upaya Memutuskan Penularan Covid 19 di Wilayah Harapan Baru Bekasi
}

\author{
Dovina Navanti ${ }^{1 *}$, Tyastuti Sri Lestari ${ }^{2}$, Solihin ${ }^{3}$, Yuri Delano Regent Montororing ${ }^{4}$, \\ Rorim Panday ${ }^{5}$ \\ ${ }^{1}$ Teknik Lingkungan, Fakultas Teknik, Universitas Bhayangkara Jakarta Raya, JI. \\ Perjuangan Raya, Marga Mulya, Bekasi Utara, Jawa Barat, 17143. Telp/fax. (021) \\ 88955871, dovina.navanti@dsn.ubharajaya.ac.id \\ ${ }^{234}$ Teknik Industri, Fakultas Teknik, Universitas Bhayangkara Jakarta Raya, JI. \\ Perjuangan Raya, Marga Mulya, Bekasi Utara, Jawa Barat, 17143. Telp/fax. (021) \\ 88955871, tyas@ubharajaya.ac.id, solihin@dsn.ubharajaya.ac.id, \\ yuri.delano@ubharajaya.ac.id \\ ${ }^{5}$ Manajemen, Fakultas Ekonomi dan Bisnis, Universitas Bhayangkara Jakarta Raya, \\ JI. Perjuangan Raya, Marga Mulya, Bekasi Utara, Jawa Barat, 17143. Telp/fax. (021) \\ 88955882, indripan@gmail.com
}

*Korespondensi : dovina.navanti@dsn.ubharajaya.ac.id

\begin{abstract}
This Community Service Program is carried out with the aim of providing information related to the transmission and prevention of the Covid 19 virus. The main target of this Community Service program is the community or local residents who often visit the Duta Harapan Housing lake, North Bekasi. With the consideration that the majority of people often do activities around the Duta Harapan lake, such as selling and recreation. Public awareness of the Covid-19 pandemic is very lacking, many people ignore Covid-19. Thus it is necessary to make efforts to increase public awareness about preventing the transmission of Covid-19, to help public awareness to provide insight or information to the public regarding several things in handling and preventing the deployment of the COVID19 Virus in New Normal life. With the number of positive patients exposed to this virus which is increasing, the community does not stop worrying and there are new policies from the government. From the results of the interview, it can be seen that the public does not know much information about Covid-19. So the solution we are doing is to provide information directly to the community. With the Community Service program through the dissemination of information, with the target of the community being able to create increased information and public understanding about Covid-19, a movement strategy is created to prevent and anticipate the deployment of Covid-19 in the local area, and the creation of information media that can be a guide for the community in dealing with the deployment of the corona virus, and continue to apply health protocols even though there is a decrease in the level of spread until the government gives instructions in the next stage of life.
\end{abstract}

Keywords : Information, deployment, transmission of covid-19

\begin{abstract}
Abstrak
Program Pengabdian Kepada Masyarakat ini dilaksanakan dengan tujuan untuk memberikan untuk memberikan informasi terkait dengan penularan dan pencegahan virus Covid 19. Target utama dari program Pengabdian Kepada Masyarakat ini adalah
\end{abstract}


masyarakat atau warga sekitar yang sering berkunjung di danau Perumahan Duta Harapan Bekasi Utara. Dengan pertimbangan bahwa mayoritas masyarakat sering beraktivitas di sekitar danau Duta Harapan, seperti berjualan dan rekreasi. Kesadaran masyarakat terhadap masa pandemi Covid-19 ini sangatlah kurang, banyak masyarakat yang menghiraukan Covid-19. Dengan demikian perlu dilakukan upaya peningkatan kesadaran masyarakat tentang pencegahan penularan Covid-19, untuk membantu kesadaran masyarakatuntuk memberikan wawasan atau informasi kepada masyarakat mengenai beberapa hal dalam menangani dan mencegah penyebaran Virus COVID-19 pada kehidupan New Normal. Dengan jumlah pasien positif terpapar virus ini yang semakin bertambah membuat warga masyarakat tak berhenti resah dan adanya kebijakan-kebijakan baru dari pemerintah. Dari hasil wawancara, dapat diketahui bersama bahwa masyarakat belum banyak mengetahui informasi mengenai Covid-19. Maka solusi yang kami lakukan memberi informasi secara langsung kepada masyarakat Dengan adanya program Pengabdian kepada Masyarakat melalui penyebaran informasi, dengan target masyarakat dapat tercipta peningkatan informasi dan pemahaman masyarakat mengenai Covid-19, tercipta suatu strategi gerakan mencegah dan mengantisipasi penyebaran Covid-19 di daerah setempat, dan tercipta media informasi yang bisa menjadi pegangan masyarakat dalam menghadapi penyebaran virus corona, serta tetap menerapkan protokol kesehatan walau terdapat penurunan tingkat penyebaran sampai pemerintah memberikan instruksi di tahapan kehidupan selanjutnya.

Kata kunci : Informasi, penyebaran, penularan covid-19

\section{PENDAHULUAN}

Di Indonesia, Covid-19 telah menjangkiti lebih dari 1,3 juta orang sejak kasus pertama diumumkan pada bulan Maret 2020, setidaknya 35.000 orang telah meninggal dunia. Namun, upaya untuk menghambat penyebaran virus Covid-19 telah menghambat kegiatan perekonomian dan Infeksi virus Covid-19 awalnya ditemukan di Wuhan, Cina pada Desember 2019 dan telah menyebar dengan cepat ke berbagai belahan dunia. Pandemi ini mempengaruhi berbagai perubahan di sektor sosial ekonomi seluruh wilayah yang terjangkit. Pada kasus Covid-19 yang berat dapat menyebabkan pneumonia, sindrom pernapasan akut, gagal ginjal, bahkan kematian. Tanda-tanda dan gejala klinis yang dilaporkan pada sebagian besar kasus adalah demam dengan beberapa kasus mengalami kesulitan bernapas dan hasil rontgen menunjukkan infiltrate pneumonia luas di kedua paru-paru, tetapi ada juga beberapa yang terjangkit namun, tanpa gejala fisik yang bisa dilihat (Handayani et al, 2020).

$\mathrm{Di}$ awal kemunculannya, virus ini mendapat beragam respons yang muncul dari masyarakat Indonesia. Sebagian mulai berhati-hati dan menerapkan pola hidup sehat, tetapi lebih banyak yang tidak peduli dan terkesan meremehkan dan tidak melakukan persiapan maupun antisipasi munculnya wabah ini di Indonesia. Bahkan ketika Covid-19 mulai menyebar dengan cepat ke berbagai daerah dan beberapa negara telah menutup akses keluar masuk, pemerintah dan warga Indonesia masih terkesan santai dan kurang melakukan tidakan pencegahan terhadap virus ini. Ketidakpastian, kebingungan, dan keadaan darurat yang diakibatkan oleh virus Corona dapat menjadi stress bagi banyak orang. Ketidakpastian dalam mengetahui kapan wabah berakhir membuat banyak golongan masyarakat terutama golongan menengah ke bawah bingung memikirkan nasib mereka. Kehidupan yang berjalan seperti biasa tanpa adanya mata pencaharian membuat mereka kesulitan memenuhi kebutuhan hidup. Keberadaan virus Corona yang mengancam setiap orang berpeluang menjadi stress bagi sebagian besar orang, dan dampaknya bisa jadi sama parahnya dengan dampak yang ditimbulkan jika terinfeksi virus Corona itu sendiri (Istiatin, Marwati, 2021).

Berdasarkan bukti yang telah diteliti, Covid-19 dapat ditularkan melalu kontak dekat dan droplet. Masyarakat yang rentan terinfeksi adalah mereka yang berhubungan dekat dengan pasien Covid-19 atau yang merawat pasien Covid-19. Di Indonesia, pemerintah sudah menghimbau masyarakatnya dengan memberikan protokol kesehatan untuk 
menghindari penularan wabah Covid-19 dengan beberapa cara, yaitu (1) cucilah tangan menggunakan sabun dan bilas dengan air mengalari. Kemudian, jangan memegang hidung, mulut, mata, serta wajah sebelum mencuci tangan dengan bersih. Cuci tangan ketika sampai di tempat kerja, tempat umum, dan setelah berpergian dari luar rumah. Cuci tangan sebelum menyiapkan dan memakan makanan. Cuci tangan setelah menggunakan toilet umum maupun toilet pribadi. Gunakan hand sanitizer/cairan pembersih tangan lainnya jika tidak ada air di sekitar, (2) Gunakan masker bila keluar rumah dan saat berada di tempat umum, (3) Tutup mulut ketika batuk atau bersin atau bila tidak menggunakan masker. Gunakan tangan ataupun tisu ketika batuk juga bersin dan jangan lupa mencuci tangan atau menggunakan hand sanitizer setelah itu, (4) Hindari keramaian dan bila berada di tempat umum beri jarak 1 meter dengan orang sekitarnya (Physical Distancing), (5) Lakukan Self Quarantine di rumah saja dan tidak berpergian kemanapun kecuali dengan alasan mendesak, (6) Pergi ke rumah sakit bila merasakan gejala dari Covid-19 (Pujaningsih \& Sucitawathi, 2020).

Guna mencegah penyebaran Covid-19 perlu melalukan penyemprotan disinfektan di tempat-tempat tertentu. Kesadaran masyarakat, menjadi kunci utama dalam upaya memutus rantai penyebaran Covid-19 yang menular dan mematikan. Berbagai program yang dilakukan, lockdown, social distancing maupun konsep lainnya, jika masyarakat tidak bisa disiplin dan punya kesadaran tinggi, maka program tersebut tidak akan pernah berhasil (Bahar, 2020). Pemerintah daerah harus memiliki strategi yang tegas agar himbauan-himbauan yang dikeluarkan dapat ditaati oleh masyarakat setempat. Meningkatkan kesadaran masyarakat dan memahami bahaya, Covid-19 salah satu program yang perlu dilakukan sosialisasi secara rutin di seluruh wilayah. Kemudian juga penyebaran informasi kepada warga untuk pola hidup bersih (Setiawan et al., 2021).

Sasaran utama dari program Pengabdian kepada Masyarakat (PKM) ini adalah masyarakat atau warga di wilayah danau Duta Harapan, dengan pertimbangan bahwa mayoritas masyarakat dan warga bekerja dalam bidang yang sangat rentan terhadap penyebaran Virus Covid-19, salah satunya yaitu berdagang di dekitar danau yang tentunya selalu bersinggungan terhadap individual yang lain sehingga protokol kesehatan sangatlah penting untuk diterapkan dan di realisasikan oleh masyarakat di sekitar danau, lemahnya kedisiplinan masyarakat terhadap pedoman kehidupan Normal Baru (New Normal) juga dapat menjadi faktor pelemah bidang ekonomi apabila penyebaran Virus Covid-19 sebagai faktor utamanya tidak dapat dicegah secara mandiri oleh masyarakat di sekitar Danau Duta Harapan. Berdasarkan hasil observasi yang telah dilakukan sebelumnya, bahwa banyak masyarakat di Perumahan Duta Harapan masih belum memiliki kesadaran tentang bahaya virus Covid-19. Dimana masyarakat masih belum menerapkan protokol kesehatan seperti social distancing, mencuci tangan secara berkala, memakai masker saat keluar rumah, penyemprotan disinfektan secara rutin. Selain itu, di sekitar danau masih jarang ditemui informasi tentang Covid19. Dengan demikian, perlu adanya sosialisasi dan penyebaran informasi bagi masyarakat dan warga setempat agar dapat mencegah penyebaran virus Covid-19, dan melalui satu wilayah ini diharapkan dapat mendukung gerakan pemerintah dalam mengurangi jumlah kasus virus Covid-19 di Indonesia.

\section{METODE PELAKSANAAN}

Berikut adalah rincian metode pelaksanaan yang dilakukan sebagai berikut :

a. Melakukan wawancara dengan masyarakat dan warga tentang era New Normal.

b. Sosialisasi dengan memberikan informasi mengenai penyebaran Covid-19 dan pentingnya menjaga kebersihan di sekitar lingkungan.

c. Program bersih-bersih sekiar danau Duta Harapan.

d. Memberikan masker kepada warga dan masyarakat sekitar yang berkunjung di danau.

e. Pemasangan spanduk/banner berisikan informasi penyebaran Covid-19.

f. Memberikan penjelasan mengenai penerapan protokol kesehatan $3 \mathrm{M}$ untuk pencegahan dan penyebaran 
g. Penyemprotan desinfektan di sekita danau Duta Harapan dan fasilitas umum.

\section{HASIL DAN PEMBAHASAN}

Capaian Program Pengabdian kepada Masyarakat ini yang utama adalah memberikan wawasan berupa informasi kepada masyarakat mengenai beberapa hal dalam menangani dan mencegah penyebaran Virus Covid-19 pada kehidupan di era New Normal. Dalam kondisi pandemi ini, pemerintah menerapkan protokol Kesehatan, salah satunya adalah memakai masker. Dilihat dari kondisi warga dan masyarakat yang berkunjung di danau Duta Harapan, rawan akan penyebaran covid-19 kesadaran akan penggunaan masker masih sangat rendah. Sasaran dalam pengabdian masyarakat ini adalah warga dan masyarakat sebagai pengunjung danau. yang masih terlihat tidak menerapkan protokol kesehatan terutama penggunaan masker. Tujuan dari program Pengabdian kepada Masyarakat ini merupakan salah satu bentuk sosialisasi yang dilaksanakan bersama masyarakat wilayah dalam program PkM ini, yaitu memberikan penyebaran informasi tentang menangani dan mencegah, serta menerapkan aturan yang telah ditetapkan pemerintah dalam mengatasi wabah virus Covid-19 yang melanda saat ini.

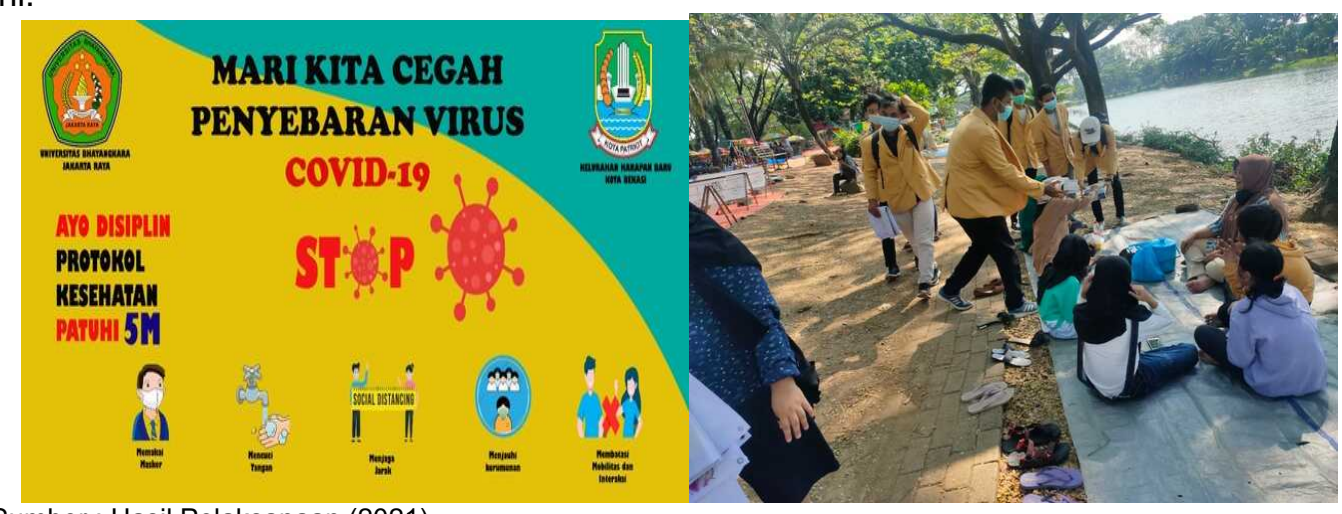

Sumber : Hasil Pelaksanaan (2021)

Gambar 1. Pelaksanaan Sosialisasi Protokol Kesehatan

Pembagian masker ini diberikan kepada masyarkat agar selalu memakai masker di luar rumah agar memutus rantai penularan Covid-19. Memakai masker sangatlah penting sebagai upaya mencegah terjadinya penularan Covid-19, terutama ketika berada di kerumunan atau berdekatan seperti di pasar, stasiun, transportasi umum (misalnya bus) dan tempat-tempat umum lainnya. Masker dapat menghalau percikan air liur yang keluar saat berbicara, menghela napas, ataupun batuk dan bersin sehingga dapat mengurangi penyebaran virus tersebut (Nasution et al., 2021) Pembagian masker ini dilakukan pada saat program PkM berlangsung. Dalam kegiatan ini dilakukan pemaparan secara lisan mengenai informasi. Covid-19 dan pentingnya menggunakan masker saat beraktivitas di luar rumah. Masyarakat khususnya pengunjung di danau banyak yang tidak memahami pentingnya memakai masker, hal ini terbukti dengan masih banyak didapati pengunjung yang tidak memakai masker sebagai upaya preventif Covid-19. Warga dan masyarakat antusias menerima informasi secara lisan dan pembagian masker. 


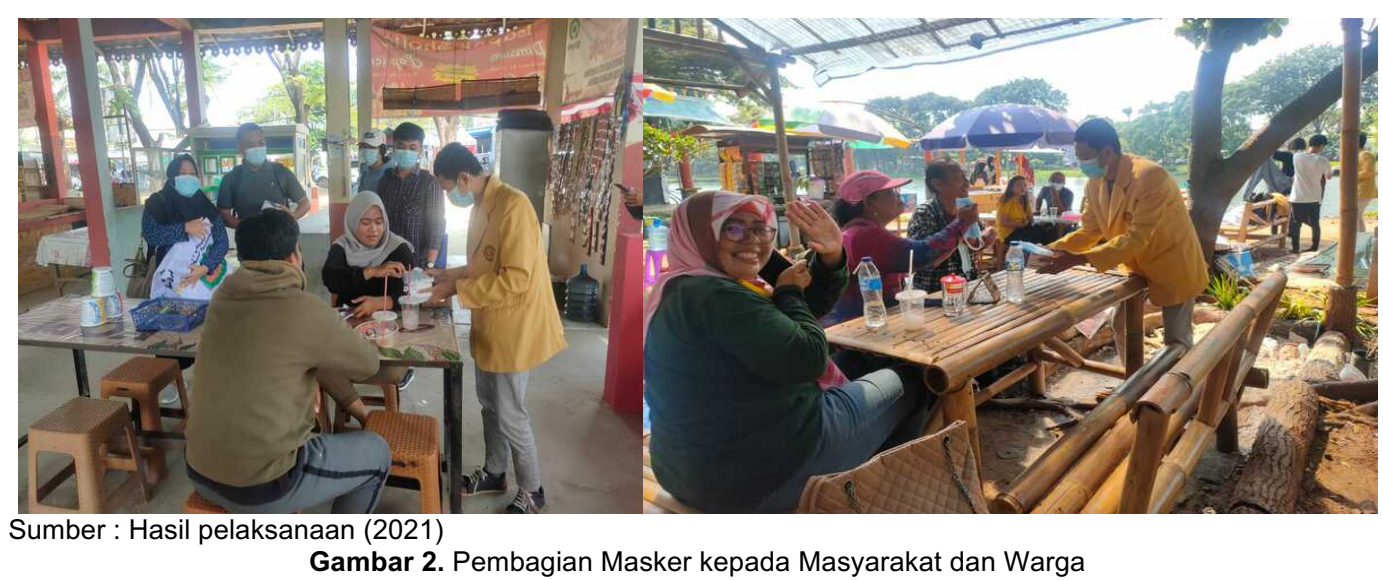

Berdasarkan hasil observasi yang telah dilakukan, kesadaran masyarakat dan warga yang berkunjung ke danau Duta Harapan dalam menjaga kebersihan lingkungan masih kurang hal ini dapat dilihat dari masih banyaknya masyarakat yang membuang sampah sembarangan, selain karena faktor kesadaran yang masih minim, dengan membuang sampah sembarang akan berpotensi timbulnya penyakit. Kebersihan lingkungan adalah keadaan bebas dari kotoran yang termasuk diantaranya bahwa proses penularan penyakit atau infeksi disebabkan oleh mikroba, kebersihan juga diartikan bebas dari virus, bakteri patogen, dan bahan kimia yang berbahaya. Masyarakat sudah barang tentu sangat perlu menjaga kebersihan lingkungan terlebih keadaan saat ini yang dapat dikatakan rentan terhadap penyebaran virus Covid-19. Covid-19 merupakan virus yang menyerang sistem pernapasan manusia yang dapat mengakibatkan penderitanya mengalami gangguan pernapasan, demam, pilek bahkan kematian.Penularan Covid-19 begitu cepat sehingga organisasi kesehatan dunia (WHO) menetapkan virus corona sebagai pandemi (Muhammad et al., 2020). Status pandemi atau epidemi global menandakan bahwa penyebaran Covid-19 berlangsung sangat cepat hingga hampir tidak ada negara di dunia yang dapat memastikan diri terhindar dari virus corona dalam upaya menekan penyebaran virus corona dengan menumbuhkan kesadaran masyarakat terhadap pentingnya hidup bersih, tim Pengabdian kepada Masyarakat menjalankan program bersih-bersih lingkungan dan diharapkan kedepannya masyarakat dan warga lebih menjaga kebersihan lingkungan di sekitar danau Duta Harapan agar terhindar dari penyebaran virus covid-19.

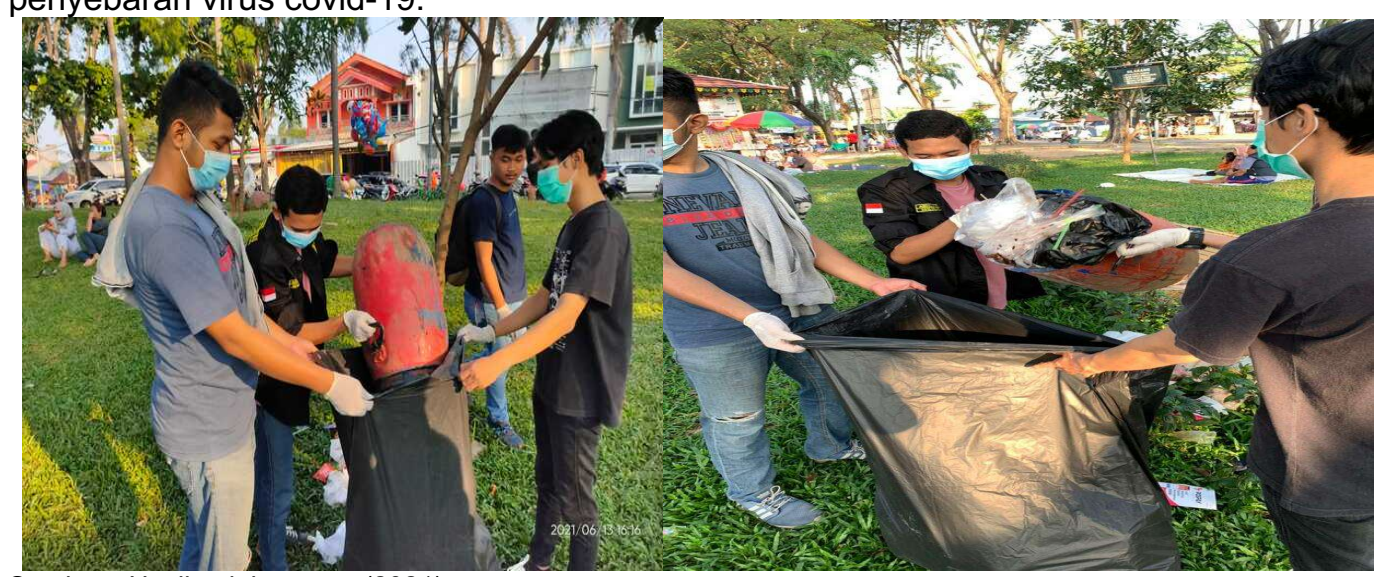

Sumber : Hasil pelaksanaan (2021)

Gambar 3. Program Bersih-bersih di sekitar Danau Duta Harapan

Penyemprotan disinfektan di lokasi danau Duta Harapan, program penyemprotan disinfektan ditujukan kepada masyarakat agar terhindar dari virus Covid-19 dan mengedukasi masyarakat selalu melakukan penyemprotan disinfektan secara berkala. Masyarakat akan kebersihan dan memutus mata rantai penularan virus Covid-19. 


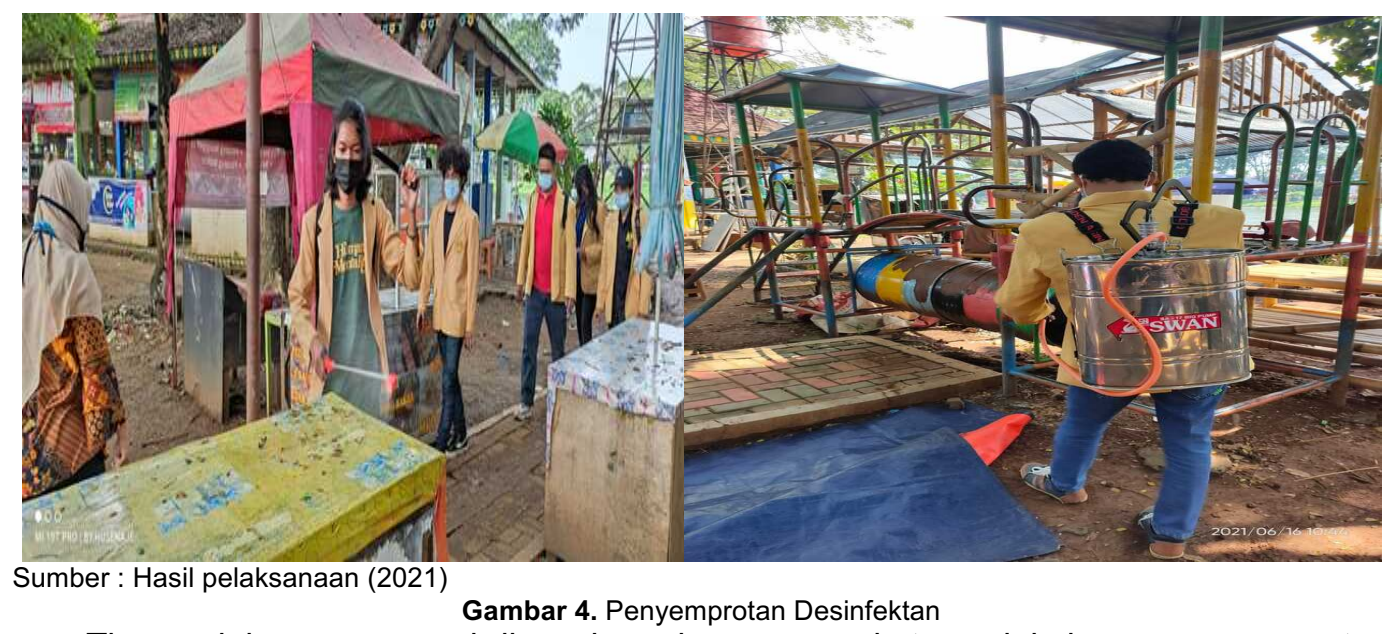

Tim pelaksana pengabdian kepada masyarakat melakukan menyemprotan disinfektan secara merata ke fasilitas umum seperti tempat duduk, dan tempat bermain anak-anak di sekitar danau perumahan duta harapan. Penyemprotan desinfektan secara berkala dapat dilakukan oleh pengurus RT atau RW di Perumahan Duta Harapan merupakan tambahan prosedur yang dapat digunakan oleh masyarakat dalam upaya pencegahan penyebaran virus Covid-19.

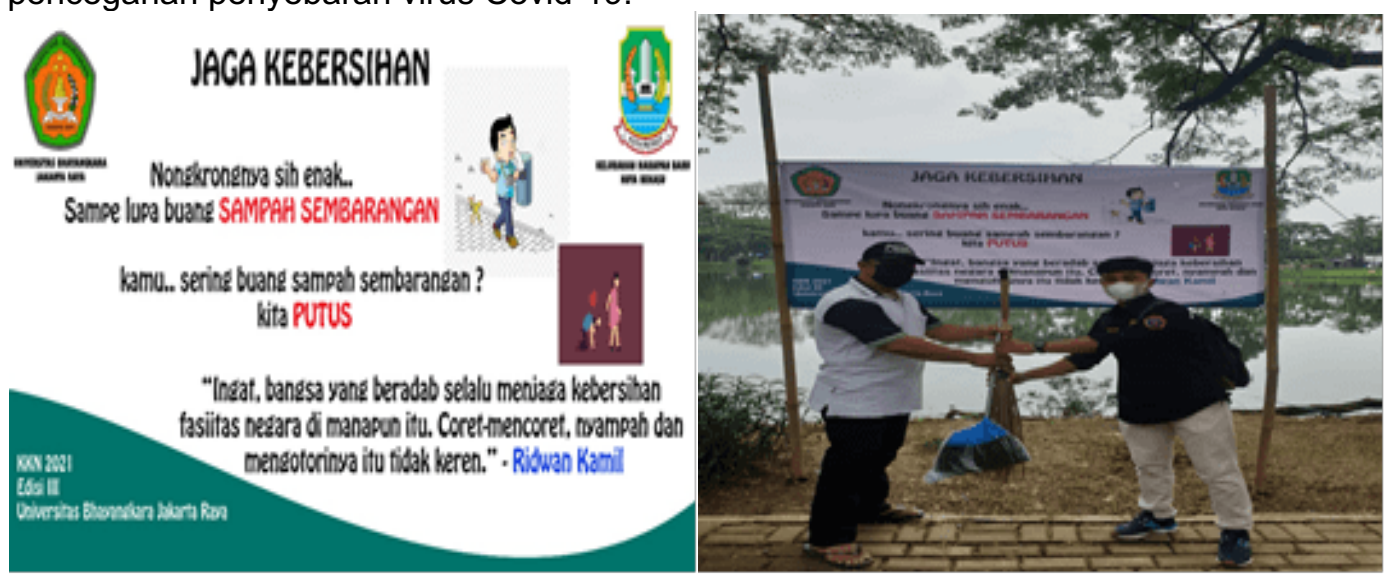

Sumber : Hasil pelaksanaan (2021)

Gambar 5. Pemasangan Spanduk Informasi Penyebaran Covid-19

Pemasangan spanduk sebagai salah satu bentuk himbauan yang diberikan kepada masyarakat di wilayah Pengabdian kepada Masyarakat melalui spanduk yang berisikan tentang pengetahuan dasar dan himbauan tentang virus corona atau Covid-19, kemudian cara-cara melawan dan antisipasi terhadap penyebaran virus tersebut, agar masyarakat di wilayah Pengabdian kepada Masyarakat dapat mengetahui dan memperhatikan, serta menggunakan himbauan ini agar dapat terhindar dari virus Covid-19. Cara ini merupakan salah satu cara yang efektif dalam menyampaikan pesan kepada masyarakat tentang virus Covid-19. Pemasangan Spanduk diletakkan di tempat-tempat yang strategis yang dapat dibaca atau dijangkau oleh warga masyarakat setempat, sehingga pencegahan penyebaran virus Corona (Covid-19) dapat di antisipisi setiap anggota, khususnya warga masyarakat wilayah Pengabdian kepada Masyarakat di danau Duta Harapan, Kegiatan ini didukung oleh warga dan masyarakat setempat. 


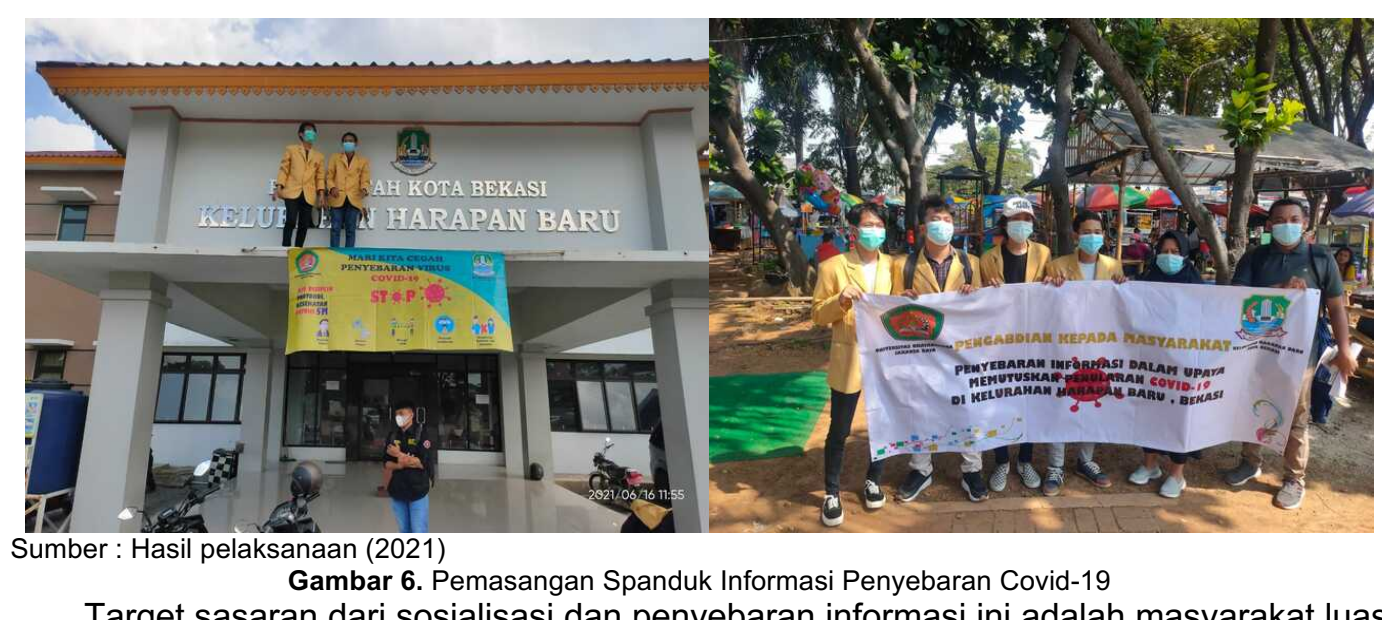

Target sasaran dari sosialisasi dan penyebaran informasi ini adalah masyarakat luas khususnya masyarakat di sekitar danau Duta Harapan. Hal ini dikarenakan masyarakat adalah sasaran utama yang paling membutuhkan informasi mengenai penyebaran Covid19. Agar lebih memahami dan meningkatakan pengetahuan bagaimana mencegah, menghadapi dan menangani penyebaran Covid-19 yang sampai saat ini kasusnya bertambah cukup signifikan. Sehingga menjadi penting pemberian informasi ini kepada masyarakat luas agar sedikit tercerdaskan dan tidak mudah termakan hoax tentang isu Covid19.

\section{KESIMPULAN DAN REKOMENDASI}

Berikut kesimpulan dan rekomendasi dari hasil pelaksanaan yaitu kegiatan Pengabdian kepada Masyarakat dengan penyebaran informasi Covid-19. mendapat sambutan yang sangat positif dari masyarakat, dimana mereka sangat membutuhkan informasi yang jelas dan benar terkait Covid-19. Tindakan pencegahandan penyebaran terhadap Covid-19 mulai diterapkan oleh masyarakat setelah pelaksanaan sosialisasi. Kemudian, dengan adanya kegiatan pembagian masker diharapkan dapat membangun kebiasaan warga dan masyarakat khususnya pengunjung danau Duta Harapan untuk selalu menggunakan masker sebagai salah satu upaya preventif agar terhindar dari penularan Covid-19. Selanjutnya, kegiatan bersih-bersih didukung dengan sangat baik oleh warga dan masyarakat, menciptakan lingkungan yang bersih dan sehat sehingga terhindar dari penyebaran Covid-19. Dan terakhir, masyarakat sadar akan penerapan dan pembiasaan perilaku hidup sehat seperti menjaga kebersihan, disiplin memakai masker, rajin mencuci tangan dengan sabun dan air bersih dan menjaga jarak serta mengurangi aktivitas di luar rumah sebagai upaya pemutusan mata rantai penyebaran Covid-19.

\section{DAFTAR PUSTAKA}

Bahar, H. (2020). PKM Upaya Pencegahan Covid-19 Melalui Keterlibatan sebagai Relawan Satgas Covid-19 dalam Penyemprotan Disinfektan Di Desa Jabungsisir.

Diah Handayani et al. (2020). Penyakit Virus Corona 2019. JURNAL RESPIROLOGI INDONESIA.

Istiatin, Marwati, F. S. (2021). Sosialisasi Dan Edukasi Program Penanganan Dan Pencegahan Penyebaran Covid-19 Guna Meredam Kepanikan Sosial Di Wilayah Desa Gentan. Angewandte Chemie International Edition, 6(11), 951-952., 03(02), 5-24.

Muhammad, F., Jailani, H., Sholihah, I., \& Utomo, D. P. (2020). Meningkatkan Kesadaran Masyarakat Dalam Menjaga Kebersihan Lingkungan Sebagai Upaya Pencegahan Penyebaran Covid-19 Di Desa Kubur Telu. SELAPARANG Jurnal Pengabdian Masyarakat Berkemajuan, 4(1), 658. https://doi.org/10.31764/jpmb.v4i1.3349 
Nasution, N. H., Hidayah, A., Sari, K. M., Cahyati, W., Khoiriyah, M., Hasibuan, R. P., Lubis, A. A., \& Siregar, A. Y. (2021). Gambaran Pengetahuan Masyarakat Tentang Pencegahan Covid-19 Kecamatan Padangsidimpuan Batunadua, Kota Padangsidimpuan. Jurnal Biomedika Dan Kesehatan, 4(2), 47-49.

Pujaningsih, N. N., \& Sucitawathi, I. G. A. A. D. (2020). Penerapan Kebijakan Pembatasan Kegiatan Masyarakat (PKM) dalam Penanggulangan Wabah Covid19 di Kota Denpasar. Moderat, 6(3), 458-470.

Setiawan, A., Saputra, H. A., \& Atmojo, M. E. (2021). Efektifitas Penyebaran Informasi Covid-19 Melalui Media Twitter Kementerian Kesehatan Republik Indonesia Dan Badan Nasional Penanggulangan Bencana. Jurnal Academia Praja, 4(1), 89-106. https://doi.org/10.36859/jap.v4i1.210 